\title{
Post binder radiography in pelvic trauma
}

\author{
Alastair Beaven, ${ }^{1,2}$ Emma Toman, ${ }^{1}$ Julian Cooper ${ }^{2}$
}

${ }^{1}$ Major Trauma Service, Queen Elizabeth Hospital Birmingham, Birmingham, UK

${ }^{2}$ Department of Orthopaedics, Queen Elizabeth Hospital Birmingham, Birmingham, UK

\section{Correspondence to}

Dr Emma Toman, emma.toman@nhs.net

Accepted 21 June 2016

\section{(1) \\ CrossMark}

\section{To cite: Beaven $\mathrm{A}$}

Toman E, Cooper J. BMJ

Case Rep Published online: [please include Day Month Year] doi:10.1136/bcr-2016216420

\section{DESCRIPTION}

A 45-year-old man was dragged behind a car during an alleged assault. He had evidence of head injury and lower limb injury. A prehospital pelvic binder was applied, and he was conveyed to a major trauma centre.

Vital signs on arrival were heart rate $102 \mathrm{bpm}$, blood pressure $84 / 65 \mathrm{~mm} \mathrm{Hg}$ and Glasgow Coma Scale (GCS) of 11 . He was intubated for decreasing GCS and CT scanned following primary survey assessment in accordance with advanced trauma life support protocols. The CT was performed with the binder in situ, and revealed a unilateral sacral fracture (Denis type 2 ) ${ }^{1}$ but no symphysis diastasis, as seen in figure 1. Secondary survey noted a swollen and bruised scrotum, along with abrasions to the lower limbs.

The binder was removed post-CT and pelvic radiograph taken within 10 min as per local major trauma centre protocol. Importantly, the radiograph, seen in figure 2, revealed significant diastasis of the symphysis, corresponding to an anteroposterior compression type mechanism of injury that was masked by the pelvic binder during $\mathrm{CT}^{2}{ }^{2}$

Other injuries included 10 rib fractures and a scalp laceration. The patient remained haemodynamically stable and was admitted to the intensive care unit, where he made good progress. He went on to have internal fixation of his pubic symphysis 8 days later.

In the early postoperative period, despite standard anticoagulation, he was diagnosed with a pulmonary embolus for which he was treated with

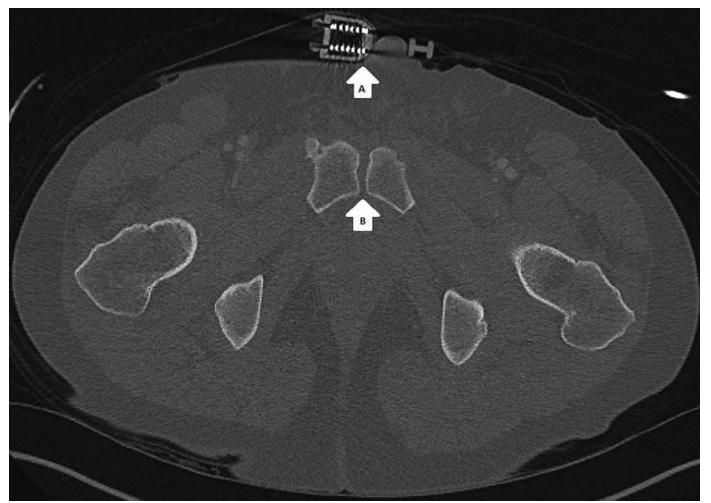

Figure 1 Axial $\mathrm{CT}$ at the level of the femoral necks showing (A) binder placement; and (B) a closed symphysis.

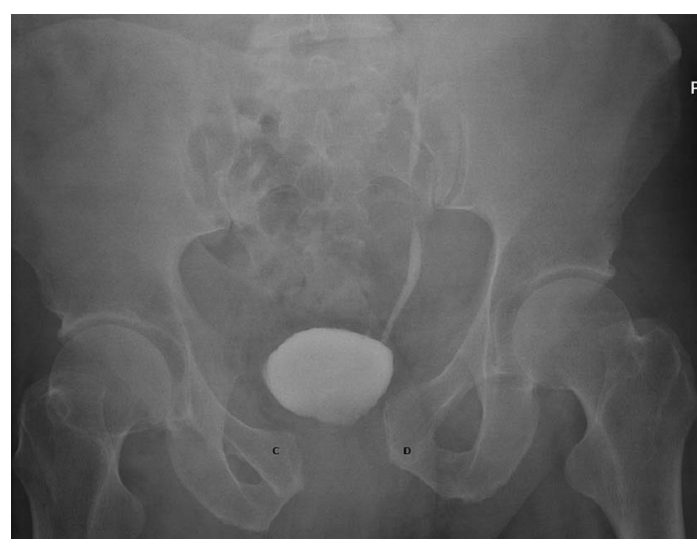

Figure 2 Anteroposterior pelvis radiograph illustrating symphysis diastasis with abnormal widening between points (C and D).

rivaroxaban over 3 months, but otherwise had no complications. At 6-month follow-up, the patient was independently mobile and had successfully returned to work.

\section{Learning points}

- Pelvic binders can mask the appearance of pelvic diastasis in trauma.

- Examination findings should accompany radiological findings in trauma.

- Always perform plain film radiography of the pelvis after removing the pelvic binder in trauma.

Acknowledgements The authors would like to acknowledge University Hospitals Birmingham in addition to the patient and his family for giving permission to use his case.

Competing interests None declared.

Patient consent Obtained.

Provenance and peer review Not commissioned; externally peer reviewed.

\section{REFERENCES}

1 Denis F, Davis S, Comfort T. Sacral fractures: an important problem. Retrospective analysis of 236 cases. Clin Orthop Relat Res 1988;227:67-81

2 Young JW, Burgess AR, Brumback RJ, et al. Pelvic fractures: value of plain radiography in early assessment and management. Radiology 1986;160:445-51. 


\section{Images in...}

Copyright 2016 BMJ Publishing Group. All rights reserved. For permission to reuse any of this content visit http://group.bmj.com/group/rights-licensing/permissions.

BMJ Case Report Fellows may re-use this article for personal use and teaching without any further permission.

Become a Fellow of BMJ Case Reports today and you can:

- Submit as many cases as you like

- Enjoy fast sympathetic peer review and rapid publication of accepted articles

- Access all the published articles

- Re-use any of the published material for personal use and teaching without further permission

For information on Institutional Fellowships contact consortiasales@bmjgroup.com

Visit casereports.bmj.com for more articles like this and to become a Fellow 